\title{
Design and Synthesis of Phenyl Boronic Acids and Benzothiophenones as Anticholinesterases
}

\author{
Eun Seok Lee, Byoung Wook Choi, Dai Il Jung, ${ }^{\star}$ Hye Jung Hwang, Jung Tae Hahn, ${ }^{\$}$ and Bong Ho Lee* \\ Deparment of Chemical Technologv. Hanbat National Lniversin, Daejeon 305-719, Korea \\ - Deparment of Chemistr., Dong-4 Chiversit, Busan 602-714, Korea \\ Livechem, INC Hanbat National Lmiversin; Daejeon 305-719, Korea \\ ${ }^{\$}$ Facultr of Life Science Engineering, Youngdong Chiversin, Chunghuk $370-701$, Korea \\ Received Wovember 5,2002
}

Key Words : Cholinesterase. Inhibition. Boronic acid. Benzothiophenones

Since cholinesterases (ChE) such as acetylcholinesterase ( $\mathrm{AChE}$ ) and butyrylcholinesterase $(\mathrm{BuChE})$ play critical roles for the neurotransmission, the detailed chemical mechanism of the ChE-catalyzed reactions are well documented. ${ }^{1.3}$ The ply siological role of $\mathrm{AChE}$ is hydroly sis of the neurotransmitter. acetylcholine $(\mathrm{ACh})$ to acetate and choline. AChE inlibitors are used as chenical warfare agents. insecticides, and drugs against Alzheimer's disease (AD). Numerous evidences suggest that the neurobiological basis of senile dementia in $\mathrm{AD}$ and related dementias is a loss of cholinergic neurons and a resultant decline in acetylcholine $(\mathrm{ACh})$ in brain regions which regulate behavioral and emotional responses. ${ }^{+6}$ This cholinergic deficit can be partly corrected by inhibiting ChEs. Well known $\mathrm{AChE}$ inhibitors such as tacrine (THA, Cognex). E2020 (Donepezil. Aricept). rivastignine (Exelon), and galantamine (Raminyl) are approved by FDA as drugs against AD. ${ }^{7.15}$ Initial research has focused on $\mathrm{AChE}$-selective agents. but it is now thought that dual inhibitors of $\mathrm{AChE}$ and $\mathrm{BuChE}$ may provide more sustained efficacy over the course of $\mathrm{AD}$ and may help to slow disease progression. ${ }^{\text {li) }}$ In the healthy brain, $\mathrm{AChE}$ predominates $(80 \%)$ and $\mathrm{BuChE}$ is considered to play a minor role in regulating brain $\mathrm{ACh}$ levels. In the $\mathrm{AD}$ brain. $\mathrm{BuChE}$ activity rises while $\mathrm{AChE}$ activity remains unchanged or declines. Therefore. both enzymes are likely to have involvement in regulating $\mathrm{ACh}$ levels and represent legitimate therapeutic targets to aneliorate the cholinergic deficit.

Abeles et $a l$. showed that fluoromethylketones are potent $\mathrm{AChE}$ inlhibitors with the inhibition constant in nano molar range. Most of them are more potent toward $\mathrm{AChE}$ over BuChE. ${ }^{11}$ It is believed that BuChE also plays important roles and thus $\mathrm{ChE}$ inlibitors should have potency selectivity. $^{1 \hat{3}, 13}$ It is klown that $m$-(N,N,N-trimethylanimonio)phenol, $m$-(N,N,N-trimethylammonio)trifluoroace tophenone are very potent reversible $\mathrm{AChE}$ inhibitors having the inhibition constant of submicro and femto molar range. respectively. ${ }^{14.15}$ It is also known that the trimethylanumonio group binds to the hydrophobic region of $\mathrm{AChE}$ known as an anionic locus previously and the serine residue in the active site binds to the carbonyl group having the trifluoromethyl group. ${ }^{1+, 15}$ Thus. if a compound has $N, N, N$-trimethylammoniophenyl group and an electropositive element. it is expected to be a good inhibitor of $\mathrm{AChE}$. It is also known that boronic acid and borinic acid bind to the $\mathrm{AChE}$ active site. Koeluler $e t$ al. synthesized a new. specific and reversible bifunctional alkylborinic acid inlubitor of $\mathrm{AChE}{ }^{\text {to }}$ Herz et al. also showed that erythrocyte membrane $\mathrm{AChE}$ is inactivated by tetraphenylboron. ${ }^{17}$

Powers et $a l$. showed that serine protease such as elastase and chymotrypsin is inactivated by isobenzofuranones and benzopyrandiones. ${ }^{18}$ If a compound has a functionality similar to the thioester of acetylthiocholine and a hydrophobic region. it is expected that the compound would bind to the $\mathrm{AChE}$ active site. Most insecticides are irreversible inhibitors of $\mathrm{AChE}$ and thus specific irreversible inthibitors are also required to develop. The benzothiophenone compounds have hydrophobic group and the carbonyl group and expected to inhibit ChEs. Since AChE and BuChE belong to the same serine hydrolases. we designed and synthesized compounds 1-4 as anticholinesterases and measured their inhibition potencies on CliEs.

\section{Experimental Section}

Materials. Electric eel AChE, type V-S lyophilized powder and horse serum BuCleE were purchased from Signa Chemical

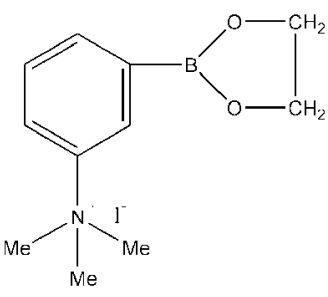

1

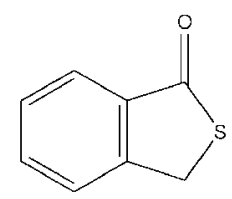

3

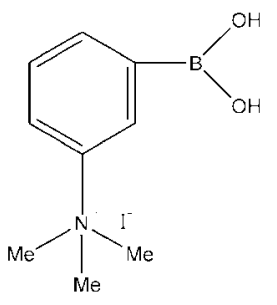

2<smiles>O=C1SCc2cccc([N+](=O)[O-])c21</smiles>

Figure 1. 
Co and was used as received. Prior to use they were dissolved in $0.1 \mathrm{M}, \mathrm{pH} 7.3$ sodium phosphate buffer. containing $0.1 \mathrm{M}$ $\mathrm{NaCl}$. Acetylthiocholine (ATCh), butyrylthiocholine (BuTCh), 5,5'-dithio-bis(2-nitrobenzoic acid) (DTNB), and buffer components were also purchased from Signa Chenical Co. Water used in experiments was distilled and deionized by passage through a mixed bead ion-exchange column. NMR spectra were obtained with a Bruker AC 200 spectrometer (200 $\mathrm{MHz}$ ) using tetramethylsilane or $\mathrm{D}_{3} \mathrm{O}$ as internal standards.

Synthesis of inhibitors. The boronic acid derivatives 1 and 2 were synthesized from 3-aminophenyl boronic acid through 3-aminophenyl-1-boro-2,5-dioxolane. ${ }^{19}$ The benzothiophenone 3 and 4 were synthesized using the known methods from ethyl $o$-methylbenzoate and ethyl 2-methy l-3nitrobenzoate. respectively. ${ }^{301}$

Synthesis of 3-aminophenyl-1-boro-2,5-dioxolane. Vacium dried 3-aninopheny lboronic acid monohydrate $(0.5$ g. 3.2 nmol) was added to a $50 \mathrm{~mL}$ one-necked flask and then $5 \mathrm{~mL}$ ethylene glycol was added to the flask under nitrogen. The mixture was heated to $100^{\circ} \mathrm{C}$ slowly and kept the temperature for $3 \mathrm{hr}$. Then. the nixture was cooled to roon temperature and $20 \mathrm{~mL}$ of methanol was added to the flask and stirred. The unreacted ethylene glycol was removed with a separatory fumnel and $\mathrm{MeOH}$ was removed with a rotary evaporator. The product was vacuum dried to give 3-aminophenyl-1-boro-2,5-dioxolane (4.84 g, 93\%): IR (neat) $V_{\text {max }}\left(\mathrm{cm}^{-1}\right) 3640,3405.3030,2925 ;{ }^{1} \mathrm{H}$ NMR (200 $\left.\mathrm{MHz} . \mathrm{D}_{2} \mathrm{O}\right) \delta 4.3 \mathrm{l}(\mathrm{s} .4 \mathrm{H}), 4.35$ (s, 2H). 6.75-7.31 (n. $\left.4 \mathrm{H}\right)$ : Mass (m/z. CD) $163\left(\mathrm{M}^{-}\right), 132.119,106.92 .65$

Synthesis of $m$-[(N,N,N-trimethylammnio)$]$ henyl $]-1$ boro-2,5-dioxolane (1). Methyl iodide (3 $\mathrm{mL}, 3.5 \mathrm{mmol}$ ) was added to a flask containing 3-aminophenyl-1-boro-2,5dioxolane $(0.5 \mathrm{~g}, 0.003 \mathrm{~mol})$ with methanol $(10 \mathrm{~mL})$ and $\mathrm{K}_{3} \mathrm{CO}_{3}(3 \mathrm{~g})$. The reaction mixture was slowly warmed to reflux for $12 \mathrm{hr}$. After completion of the reaction the reaction misture was cooled to room temperature. After filtration of $\mathrm{K}_{3} \mathrm{CO}_{3}$. methyl iodide was removed with a rotary evaporator and dried in a vacuum to give a white solid $(0.66 \mathrm{~g} .90 \%)$ : IR $(\mathrm{KBr}) v_{\max }\left(\mathrm{cm}^{-1}\right)$ 3030. 2960. 2925: ' H NMR (200 MHz. $\left.\mathrm{D}_{2} \mathrm{O}\right) \delta 3.36(\mathrm{~s} .4 \mathrm{H}) .3 .64(\mathrm{~s} .9 \mathrm{H}), 7.49-7.88(\mathrm{~m} .4 \mathrm{H})$ : Anal. calcd for $\mathrm{C}_{11} \mathrm{H}_{17} \mathrm{BNO}$ I: C. $39.70: \mathrm{H}, 5.15: \mathrm{N}, 4.21$. Found: C. $39.72:$ H. $5.13:$ N. $4.19 \%$

Synthesis of $m$-[( $N, N, N$-trimethylammnio $)]$ henyl]boronic acid (2). Compound $1(0.5 \mathrm{~g} .0 .0024 \mathrm{~mol})$ was added to a one-necked round bottomed flask having $20 \mathrm{~mL}$ of $15 \% \mathrm{HCl}$ solution. The reaction mixture was warmed to $80^{\circ} \mathrm{C}$. After 1 hr the reaction mixture was cooled to room temperature. The reaction mixture was neutralized with $10 \% \mathrm{NaOH}$ solution and extracted the product with dichloromethane. Dichloromethane was removed with a rotary evaporator and the product was vacuum dried to give a brownish solid $(0.61$ g. $83 \%$ ): IR (KBr) $v_{\max }\left(\mathrm{cm}^{-1}\right) 3630,3030.2978:{ }^{1} \mathrm{H}$ NMR (200 MHz. D 2 O) $\delta 3.41$ (s. 9H). 3.73 (s. $2 \mathrm{H}) .7 .58(\mathrm{~m} .4 \mathrm{H})$ : Anal calcd for $\mathrm{C}_{9} \mathrm{H}_{15} \mathrm{BNO}=\mathrm{I}: \mathrm{C} .35 .22: \mathrm{H}, 4.93: \mathrm{N}, 4.56$. Found: C. 35.16: H. 4.93: N. 4.55\%.

Synthesis of $3 H$-benzo[C]thiophen-1-one (3). To a solution of ethyl o-metlyylbenzoate $(8.21 \mathrm{~g} .50 \mathrm{mmol})$ and benzoylperoxide ( $10 \mathrm{mg} .41 .3 \mathrm{mmol}$ ) in carbon tetrachloride (125 $\mathrm{mL}$ ) was added $N$-bromosuccinimide $(8.90 \mathrm{~g} .50 \mathrm{mmol}$ ) and refluxed for 6 lur. After completion of the reaction the mixture was filtered and evaporated. The residue in acetone $(50 \mathrm{~mL})$ was mixed with thiourea $(4.19 \mathrm{~g} .55 \mathrm{mmol})$ and refluxed for $5.5 \mathrm{hr}$. After removal of acetone by evaporation, the obtained thiouronium salt was warmed to $80-90^{\circ} \mathrm{C}$ in 20 $\% \mathrm{NaHCO}_{3}$ solution $(50 \mathrm{~mL})$ under nitrogen for $2 \mathrm{hr}$. Then, the solution was acidified with $20 \% \mathrm{HCl}$ solution. The oily residue was subjected to silica gel column chromatography (eluent; hexane : ethyl acetate $=10: 1, v / v)$ to give $3(4.81 \mathrm{~g}$. $64 \%$ ): m.p. $58-60^{\circ} \mathrm{C}$ (Ref. ${ }^{17}$ m.p. $58-60^{\circ} \mathrm{C}$ ): IR (KBr) $v_{\text {max }}$ $\left(\mathrm{cm}^{-1}\right) 3030,1686.1595,1237,{ }^{1} \mathrm{H}$ NMR $\left(200 \mathrm{MHz}, \mathrm{CDCl}_{3}\right)$ $\delta 4.45$ (s. $2 \mathrm{H}$ ), $7.38-7.97$ (n. $4 \mathrm{H}$ ); Anal calcd for $\mathrm{C}_{8} \mathrm{H}_{6} \mathrm{OS}$ : C. $63.97: \mathrm{H}, 4.03: \mathrm{S} .21 .35$. Found: C. $63.84 ; \mathrm{H}, 4.02 ; \mathrm{S}$, $21.30 \%$.

Synthesis of 4-nitıo-3H-benzo $[C]$ thiophen-1-one (4). To a solution of etlyy 2-methyl-3-nitrobenzoate (10.45 g. 50 mmol) and benzoylperoxide (10 $\mathrm{mg} .41 .3 \mathrm{mmol}$ ) in carbon tetrachloride $(125 \mathrm{~mL})$ was added $N$-bromosuccinimide $(8.90 \mathrm{~g} .50 \mathrm{~mol})$ and refluxed for $7 \mathrm{lur}$. After completion of the reaction the mixture was filtered and evaporated. The residue in acetone $(50 \mathrm{~mL})$ was mixed with thiourea $(4.19 \mathrm{~g}$. $55 \mathrm{mmol}$ ) and refluxed for $5.5 \mathrm{hr}$. After removal of acetone by evaporation, the obtained thiouronium salt was warmed to $80-90{ }^{\circ} \mathrm{C}$ in $20 \% \mathrm{NaHCO}_{3}$ solution $(50 \mathrm{~mL})$ under nitrogen for $2 \mathrm{hr}$. Then, the solution was acidified with $20 \%$ $\mathrm{HCl}$ solution. The oily residue was subjected to silica gel column chromatography (eluent: hexane : ethyl acetate $=$ $10: 1, v / v)$ to give $4(4.39 \mathrm{~g}, 45 \%)$ : m.p. $105^{\circ} \mathrm{C}:$ IR $(\mathrm{KBr})$ $v_{\max }\left(\mathrm{cm}^{-1}\right) 3030,1685.1595,1530 ;{ }^{1} \mathrm{H}$ NMR $(200 \mathrm{MHz}$, $\mathrm{CDCl}_{2}$ ): $\delta 4.40$ (s. $2 \mathrm{H}$ ), 7.04 (d. $\left.1 \mathrm{H}\right), 7.29$ (d. $1 \mathrm{H}$ ), 7.72 (t. IH); Anal. calcd for $\mathrm{C}_{8} \mathrm{H}_{5} \mathrm{NO}_{3} \mathrm{~S}: \mathrm{C}$. 49.23: H. 2.58; N, 7.18; S. 16.43. Found: C. 49.28; H, 2.53; N. 7.19: S. 16.32\%.

Cholinesterase assay. AChE-catalyzed hydrolysis of the thiocholine esters was monitored by following production of the thioanion of nitrobenzoic acid at $412 \mathrm{~nm}$ by the Ellmans coupled assay:- Assays were conducted on HP8452A or HP8453A diode array UV-visible spectrophotometers and the cell compartments were thermostatted by circulating water or Peltier temperature controller, respectively. In $\mathrm{BuChE}$ assay. BuTCh was used as a substrate.

\section{Results and Discussion}

The designed compounds were synthesized and tested as anticholinesterases. They turned out to be $\mathrm{ChE}$ inhibitors with the inhibition constant shown in Table 1 . The inhibition constant obtained by a replot of $\mathrm{K}_{\mathrm{m}} / \mathrm{V}_{\mathrm{max}} v_{s}$. inhibitor concentration ranges from $\mu \mathrm{M}$ to $n \mathrm{M}$. The boronic acid and its protected form are effective inhibitors of $\mathrm{AChE}$ and $\mathrm{BuChE}$. The inhibition constant for AChE. $78 \mathrm{nM}$ is close to that of the most potent $\mathrm{AChE}$ inhibitors such as tacrine and huperzine A. Since the inhibitors increased the Michaelis constant while they have little effect on the maximal velocities. the inhibition mechanism is mixed (data not shown) 
Table 1. The anticholinesterase activities of the compounds

\begin{tabular}{cccc}
\hline Compound & $\begin{array}{c}\mathrm{K}_{\mathrm{t}} \text { for } \mathrm{AChE} \\
(\mu \mathrm{M})\end{array}$ & $\begin{array}{c}\mathrm{K}_{\mathrm{s}} \text { for BuChE } \\
(\mu \mathrm{M})\end{array}$ & $\begin{array}{c}\mathrm{K}_{\mathrm{J}}(\mathrm{BuClE}) \\
\mathrm{K}_{3}(\mathrm{AClE})\end{array}$ \\
\hline 1 & $0.137 \pm 0.005$ & $74.2 \pm 6.6$ & 541 \\
2 & $0.078 \pm 0.003$ & $23.5 \pm 1.0$ & 301 \\
3 & $59.8 \pm 3.1$ & $4894 \pm 358$ & 82 \\
4 & $11.8 \pm 1.2$ & $341 \pm 30$ & 29 \\
\hline
\end{tabular}

though it is close to competitive inhibition. Compounds 1 and 2 did not show any slow binding inhibition. $\mathrm{AChE}$ and conipound 2 were incubated and the enzyme activity was measured at different times. There is no change in the inhibition potency as time goes for $\mathrm{l} \mathrm{hr}$. The protection of the two hydroxyl group in the boronic acid does not have a significant effect on the inhibition constant. The protection decreased the inhibition potency only by 2 -fold. The trimethylanmoniophenyl group of $\mathbf{1}$ and $\mathbf{2}$ is believed to bind to the hydrophobic site of $\mathrm{ChE}$ active site. The active site of $\mathrm{AChE}$ and $\mathrm{BuChE}$ composed of hydrophobic anino acid residues such as phenylalanine. tryptophan, and tyrosine. ${ }^{2.2 . t+}$ This kind of $\pi$-charge interaction plays an important role in ligand binding to protein active site ${ }^{55}$ The positive charge on the nitrogen atom of trimethylanmonio group interacts with the hydrophobic amino acid residues in $\mathrm{ChE}$ active site. This $\pi$-charge interaction is much stronger than normal hydrogen bond and the binding of $\mathrm{ACh}$ to the $\mathrm{AChE}$ active site is due to this interaction. The active site serine residue bind to boron atom to enhance the binding affinity of 1 and 2.

The benzothiophenone (3) and the nitro substituted one (4) inhibit $\mathrm{ChE}$ with much less potency. The nitro group in 4 increased the inhibition potency by 5 fold toward $\mathrm{AChE}$ compared to 3 . These compounds are not good inhibitors for $\mathrm{BuChE}$, either. Compound 3 is the least potent $\mathrm{BuChE}$ inhibitor with the inhibition constant of $4.9 \mathrm{mM}$ among the tested compounds. This may due to the increased hydrophobic site of $\mathrm{BuClE}$ and the absence of any electronic effect by' the nitro group. As the inhibition potency decrease the $\mathrm{K}_{\mathrm{i}}$ $(\mathrm{BuChE}) / \mathrm{K}_{\mathrm{j}}(\mathrm{AChE})$ also decreases. meaning the selectivity decreases. The more potent inhibitor toward AChE 1 and $\mathbf{2}$ are more selective than benzothiophenones. The irreversible inhibition of ChEs with benzothiophenones is underway.

Recent evidence suggests that $\mathrm{BuChE}$ may also have a role in the etiology and progression of $\mathrm{AD}$ beyond regulation of synaptic ACh levels. Experimental evidence from the use of agents with enhanced selectivity for $\mathrm{BuClE}$ (cymserine. $\mathrm{MF}-8622$ ) and $\mathrm{ChE}$ inlibitors such as rivastigmine. which have a dual inhibitory action on both $\mathrm{AChE}$ and $\mathrm{BuChE}$. indicate potential therapentic benefits of inhibiting both $\mathrm{AChE}$ and $\mathrm{BuChE}$ in $\mathrm{AD}$ and related dementias. ${ }^{26.27}$ In this respect. the boronic acid inhibitors has the potential for the further refinement as ChEs inhibitors.
Acknowledgment. We wish to thank the Korea Science and Engineering Foundation (KOSEF) for the financial support tlurough the Advanced Material Research Center for Better Environment at Hanbat National University.

\section{References}

1. Rosenberny, T. L. Adv Enzymol. Relat. Areas Aol Biol. 1975. 43 . 103.

2. Quinn. D. M.: Pryor. A. N.: Selwood. T.: Lee. B. H.: Achesont. S A.: Barlow: P. N. In Cholnesterases: Sinture, Function. Mechanism. Gentetics, and Cell Biolog: Massoulie, J., Bacou. F.. Barnard. F.. Chatonnet, A., Doctor, B. P., Quinn, D. M., Eds:- American Chemical Society: Washington. DC, 1991; pp 252-257.

3. Selwood. T.: Feaster. S. R.: States. M. J.: Pryor. A. N.: Quint1. D. M. J.Ant. Chent Soc. 1993. 113. 10477.

4. Davies, P; Maloney. A. J. F. Lancet 1976, 2. 1403.

5. Parnetti, L:; Senin, U.: Mecocei. P. Drugs Futtwe 1997, 53,752

6. Giacobini. E. Jph. J. Pham acol. 1997, 74, 225.

7. Finkelstein. B. L.: Benner. E. A.: Hendrisson. M. C.: Kranis. K T.: Rauh. J. T.: Sethuraman. M. R.: MeCan11. S. F. Bioorg. Med. Chent 2002. 10.599.

8. Rocca. P.: Cocuzza. E.: Marchiaro. L.: Bogetto, F. Prog Nenopsychophamacol. Biol. Psychiatry 2002. 26. 369.

9. Potkin. S. G.: Anand. R.: Fleming. K.: Alva. G.: Keator. D.: Carreont. D.: Messina. D.: Wu. J. C.: Hartman. R.: Fallon. J. H. Iht. J. Nertropstchophamacol 2001 . +. 223.

10. Basrant. T.: Mewies. M.: Mathews. F. S.: Scrutton. N. S. Biochent. 1997. 36, 1989

11. Allen. K. N.: Abeles. R. H. Biochemisty 1989. $28,8466$.

12. Greig. N. H.; Utsuki. T; Yu. Q. S.: Zhu, X; Holloway, H. W. Perry. T. A.: Lee. B. H.: Ingram. D. K.: Lahari. D. K. Cum Med. Res \& Opinions 2001. $17(3)$. 1 .

13. Greig. N. H.: Utsuki. T.: Yu. Q. S.: Zhu. X: Holloway. H. W.: Perry, T. A.: Lee. B. H.: Ingram, D. K.; Lahari. D. K. Azheiner's Insights 2001. 7, 1 .

14. Nair. H. K.: Lee. K.: Quinn. D. M. J. Am. Chem. Soc. 1993, 115. 9939.

15. Nair. H. K.: Seravalli. T.: Arbuckle. T.: Quint1. D. M. Biochentisty 1994.33.8566.

16. Koehler, K. A.; Hess, G. P. Biochentism 1974. 13, 5345

17. Herz. F.; Kaplan. E.: Luna. I. G. Experientia 1971. 27, 1260.

18. Hemmi. K. Harper, J. W.; Powers. J. C. Biochemistry 1985, 24. 1841.

19. Tsutomu. I.-i.: Nakashima. K.: Shinkai. S.: Araki. K. Tetrahedon 1998. $5+.8678$

20. Végh, D.: Morel. J.; Decroix. B.: Zảlupsky. P. Syn. Comm. 1992. 22. 2057.

21. Pal. R.: Murty: K.: Mal. D. Sy. Comm. 1993. 23. 1555.

22. Ellman. G. L.: Coutney. K. D.: Andres. V.. Ir.: Featherstone. R. M. Biochem. Pham

23. Bourne. Y: Taylor. P.: Bougis. P. E.: Marchot. P. J. Biol. Chent. 1999. 29,2963

24. Harel. M.; Kleywegt, G. J.: Ravelli, R. B.: Silman, I.: Sussman, J. L. Structure $1995.15,1355$.

25. Dougherty. D. A. Science 1996. 271. 163.

26. Greig. N. H.: Utsuki. T.: Yu. Q.: Zhu. X.: Holloway. H. W.: Perry. T.: Lee. B.: Ingram. D. K.: Lahiri. D. K. Curr. Hed Res. Opinions: 2001. 17,159

27. Bullock. R. Iht J. Chin. Pract. 2002. 56,206 